\title{
Sina and Sinb genes in triticale do not determine grain hardness contrary to their orthologs Pina and Pinb in wheat
}

\author{
Sebastian Gasparis ${ }^{1}$, Waclaw Orczyk ${ }^{2}$ and Anna Nadolska-Orczyk ${ }^{1 *}$
}

\begin{abstract}
Background: Secaloindoline a (Sina) and secaloindoline b (Sinb) genes of hexaploid triticale ( $x$ Triticosecale Wittmack) are orthologs of puroindoline a (Pina) and puroindoline b (Pinb) in hexaploid wheat (Triticum aestivum L.). It has already been proven that RNA interference (RNAi)-based silencing of Pina and Pinb genes significantly decreased the puroindoline $a$ and puroindoline $b$ proteins in wheat and essentially increased grain hardness ( $J$ Exp Bot 62:4025-4036, 2011). The function of Sina and Sinb in triticale was tested by means of RNAi silencing and compared to wheat.

Results: Novel Sina and Sinb alleles in wild-type plants of cv. Wanad were identified and their expression profiles characterized. Alignment with wheat Pina-D1a and Pinb-D1a alleles showed 95\% and 93.3\% homology with Sina and Sinb coding sequences. Twenty transgenic lines transformed with two hpRNA silencing cassettes directed to silence Sina or Sinb were obtained by the Agrobacterium-mediated method. A significant decrease of expression of both $\sin$ genes in segregating progeny of tested $T_{1}$ lines was observed independent of the silencing cassette used. The silencing was transmitted to the $T_{4}$ kernel generation. The relative transcript level was reduced by up to $99 \%$ in $T_{3}$ progeny with the mean for the sublines being around $90 \%$. Silencing of the Sin genes resulted in a substantial decrease of secaloindoline $a$ and secaloindoline $b$ content. The identity of SIN peptides was confirmed by mass spectrometry. The hardness index, measured by the SKCS (Single Kernel Characterization System) method, ranged from 22 to 56 in silent lines and from 37 to 49 in the control, and the mean values were insignificantly lower in the silent ones, proving increased softness. Additionally, the mean total seed protein content of silenced lines was about $6 \%$ lower compared with control lines. Correlation coefficients between hardness and transcript level were weakly positive.
\end{abstract}

Conclusions: We documented that RNAi-based silencing of Sin genes resulted in significant decrease of their transcripts and the level of both secaloindoline proteins, however did not affect grain hardness. The unexpected, functional differences of Sin genes from triticale compared with their orthologs, Pin of wheat, are discussed.

Keywords: RNAi silencing, Sin, Triticale, Secaloindoline, Wheat, Puroindoline, Agrobacterium, Gene function, Orthologs

\footnotetext{
* Correspondence: a.orczyk@ihar.edu.pl

${ }^{1}$ Department of Functional Genetics, Plant Breeding and Acclimatization Institute - National Research Institute, Radzikow, 05-870 Blonie, Poland Full list of author information is available at the end of the article
} reproduction in any medium, provided the original work is properly cited. The Creative Commons Public Domain Dedication waiver (http://creativecommons.org/publicdomain/zero/1.0/) applies to the data made available in this article, unless otherwise stated. 


\section{Background}

Grain hardness is an important factor of cereal quality influencing the end use of common wheat [1,2]. It has a strong effect on milling properties, flour granularity and starch granule integrity. Soft wheat contains high levels of both puroindoline proteins, puroindoline a (PINA) and puroindoline $b$ (PINB), which form friabilin [3-5]. These small proteins are unique among plant proteins, having a cysteine-rich backbone and tryptophan-rich domain [6]. Their lipid-binding properties influence dough quality [7] as well as plant resistance to pathogens [8-11]. Puroindoline-like proteins [12] in triticale are named secaloindoline $\mathrm{a}$ and secaloindoline $\mathrm{b}[13,14]$. The function of Sin genes coding secaloindoline proteins is not well characterized.

Hexaploid triticale (AABBRR) is a synthetic crop developed from hybridization of durum wheat (AABB), reproducing very hard type grains with very soft type grains rye (RR). It exhibits a high level of variation for grain hardness [15]. Thus this species is very interesting to investigate the mechanism of grain hardness. As a hybrid of wheat and rye, it combines the yield potential and grain quality of wheat with the disease and environmental tolerance (soil and weather) conditions of rye. It is grown mostly for forage or fodder, although some triticale cultivars are grown for bread or are components of health food products.

Sina and Sinb genes in triticale (x Triticosecale Wittmack) are orthologs of Pina and Pinb in wheat (Triticum aestivum L.). Both species are allohexaploids containing the A, B and R or A, B and D genomes, respectively. The $\operatorname{Sin}$ genes are located in the Hardness locus of $5 \mathrm{R}[14,16]$ and the Pin genes in the hardness locus of $5 \mathrm{D}[3,17,18]$. The well-documented, main role of Pin genes in wheat is to control grain hardness (reviewed in [19-21]). Specific mutation or RNAi silencing of both Pin genes decreased the level of puroindolines and increased grain hardness up to the level of hard T. turgidum var. durum cultivar [22]. The function of their orthologs, $\operatorname{Sin}$ genes in triticale, is expected to be similar; however, a few papers on the subject have reported contradictory data $[13,14,23]$. The first report on the conservation of Pina and Sina sequences reported that the homology is more than $99 \%$, but Sina sequences were not found [13]. No PCR product was amplified with Pina specific primers in rye and triticale, but the authors documented discrete allelic variation at the secaloindoline loci in rye. Ramirez et al. [23] demonstrated the occurrence of a product of $\operatorname{Sin}$ genes, friabilin, but there was no correlation between the content of the starch-granule associated friabilin-like protein and grain hardness (measured by PSI). Li et al. [14] detected genes orthologous to puroindoline $b$ and found that the level of starch granule-associated friabilin, which is the final product of the genes, was high in soft triticale lines and very low in hard lines. However, two newly found alleles containing substituted amino acids did not influence the phenotype. No relationship between grain hardness and secaloindoline alleles have been reported in rye, since all tested genotypes displayed a soft phenotype [14].

RNAi (RNA interference) technology is a great tool for silencing of native gene expression as well as for analysis of gene function and obtaining modified plants. The technology is especially useful in the case of polyploid cereals, such as wheat [22,24-27] or triticale, for which all homologous genes and their copies might be silenced. Application of RNAi technology is possible with the well-established genetic transformation method. We have already proved that for silencing of developmentally regulated genes Agrobacterium-mediated transformation is the method of choice, compared with the biolistic one [28]. Based on conclusions from our research and earlier documented preferences for cereal transformation [29,30], Agrobacterium-mediated transformation of triticale, first established by us [31], was applied in the present research.

As previously documented, the RNA-mediated silencing of one of the Pin genes in wheat simultaneously decreased the expression of the other, which resulted in a significant increase of grain hardness [22]. This is the first report on the RNAi silencing of their orthologs, $\operatorname{Sin}$ genes in triticale, with the aim of explaining their function. We proved the possibility of using RNAi technology in another hexaploid cereal species. Opposite to wheat, no negative correlation between very low expression level and increase of grain hardness was documented. The silencing was transmitted to the $\mathrm{T}_{4}$ kernel generation.

\section{Results}

Sequence comparison of novel Sina and Sinb alleles from cv. Wanad to other known Sin and to Pina and Pinb of wheat and their expression profiles

Full coding sequences of Sin genes of the wild plants of cv. Wanad were amplified with specific primers and sequenced. Comparison of Sina from cv. Wanad (deposited in GenBank under accession number KC784350) with two known Sina sequences from Secale cereale revealed 22 nucleotide substitutions and 3 nt insertions in one allele (AJ249932.1) [14] and only 4 nt substitutions in the second one (DQ269850.1) [32]. The Sinb sequence from cv. Wanad was deposited in GenBank under accession number KC784351. Two other accessions, AY667061.1 and AY667062.1 [13], differ to Sinb in one codon deletion and three or four nucleotide substitutions. The accession DQ269886.1 [32] revealed four nucleotide substitutions (Additional file 1).

Alignment/homology matrix with wheat Pina-Dla (DQ363911.1) and Pinb-D1a (DQ363913.1) alleles showed 
95\% and 93\% homology to Sina (KC784350) and Sinb (KC784351) coding sequences of the tested triticale cultivar. Each ortholog contained at least 3 long fragments showing 100\% homology: 23, 45, 53 nucleotides for Sina and 26, 30 and 97 nucleotides for Sinb. Deduced amino acid sequences showed 91.8\% and 90\% homology with PINA (ABD72477.1) and PINB (ABD72479.1) respectively. DNA sequence alignment of Pina-D1a (DQ363911.1) and Pina-D1a sequenced from wheat cvs. Kontesa and Torka with Sina of cv. Wanad revealed 22 substitutions and 3 deletions. It corresponds with 12 amino acid substitutions and one amino acid deletion. DNA sequence alignment of Pinb-D1a (DQ363913.1), Pinb-D1c sequenced from cv. Kontesa and Torka with Sina of cv. Wanad showed 32 substitutions and one insertion of three nucleotides (Additional file 2).

Expression profiles of $\operatorname{Sin}$ genes in developing spikes from 8 DAP to 32 DAP of wild type plants of $\mathrm{cv}$. Wanad were determined (Figure 1). The relative level of Sina transcript was growing up to 26 DAP and the peak was 54 times higher compared to $8 \mathrm{DAP}$. The transcript of Sinb started to accumulate from 8 DAP up to 26 DAP, reaching 44 times higher expression compared to 8 DAP. There was a respective decline of profiles of both genes from 26 DAP to 32 DAP. The profiles were parallel to each other, with a $20 \%$ to $30 \%$ lower transcript level of Sinb compared with Sina.

\section{Agrobacterium-mediated transformation of triticale with hpRNA type of silencing cassettes}

In total, 4454 immature embryos were transformed with the (Pina), (Pinb), cotransformed with both (Pina) plus (Pinb), and with the pMCG161 empty (not containing a silencing cassette) vector (Table 1). 70 plants from 28 callus lines were selected on phosphinothricin. Out of 57 PCR tested plants 20 of them were confirmed to be transgenic with at least 3 pairs of specific primers. The transformation rate ranged from $0.00 \%$ in the case of cotransformation to $2.4 \%$ with the mean of $1.14 \%$.

\section{Silencing of Sin genes in transgenic lines through generations}

The decrease of transcript level in silenced plants was determined in 26 DAP spikes by quantified RT-PCR. It was measured in 6 plants of each of $8 \mathrm{~T}_{1}$ lines transformed with the (Pina) cassette and $2 \mathrm{~T}_{1}$ lines transformed with the (Pinb) cassette. Relative level of expression was related to non-silenced, control plants $(=1.00)$, which were transformed with the empty pMCG161 vector. The transcript level for Sina ranged from 0.18 to 1.43 and for $\operatorname{Sin} b$ from 0.18 to 1.47 (Figure 2a). The highest level of silencing, reaching about $80 \%$ decrease of transcript, was observed in the individual plants of segregating $\mathrm{T}_{1}$ lines: $6 \mathrm{~A}, 12 \mathrm{~A}, 29 \mathrm{~A}$, $30 \mathrm{~A}$, and 31A. The lowest mean rate of both $\operatorname{Sin}$ transcripts was about 0.4 in line 29A. The levels of silencing for both Sin genes were similar and independent of the silencing cassette used.

Individual $T_{1}$ plants showing in most cases the lowest transcript levels were selected to test the segregation and the level of silencing in the $\mathrm{T}_{2}$ generation. There were 9 lines silenced with (Pina) and four silenced with (Pinb) (Figure 2b). The range of silencing for the Sina gene was from 0.01 to 1.48 and for $\operatorname{Sinb}$ from 0.02 to 2.25. Most of the individual $\mathrm{T}_{2}$ plants were silenced and the transcript was reduced up to $99 \%$. The level of silencing of both genes was similar, independent of the silencing cassette used. The highest differences in the levels of expression among individual plants were observed in 2E1 and 6A1 lines. Similar levels of expression were observed among plants of $2 \mathrm{~J} 1,7 \mathrm{~F} 1$ and $37 \mathrm{~A} 1$ lines. In

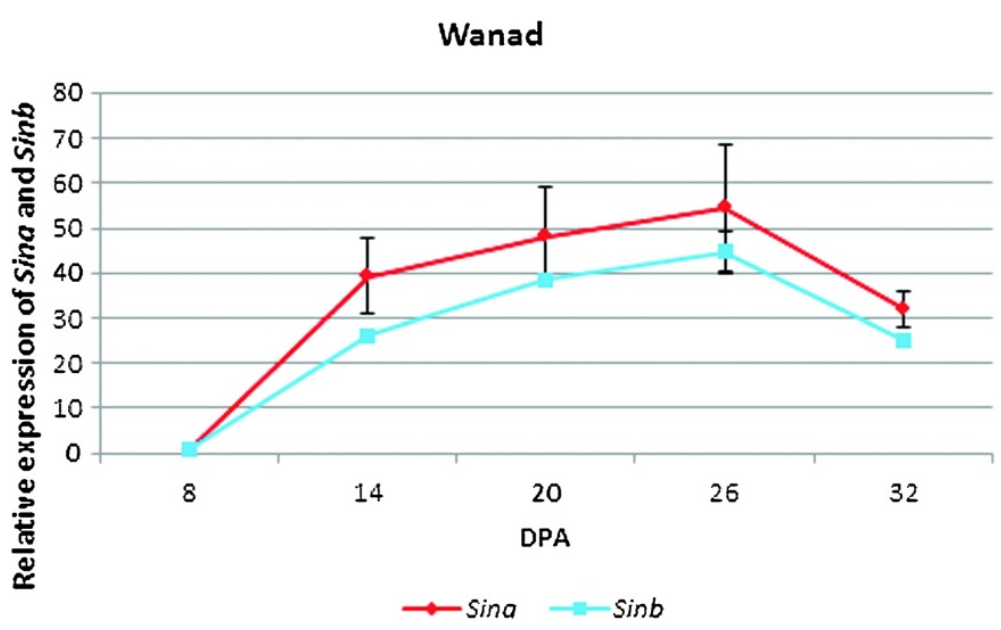

Figure 1 Profiles of Sina (upper line) and Sinb (lower line) gene expression in developing spikes of the non-transgenic plants of cv. Wanad from $8^{\text {th }}$ to $32^{\text {nd }}$ day after pollination (DAP). 
Table 1 Number of selected lines and plants, PCR positive plants and transformation efficiency of cultivar Wanad transformed with (Pina), (Pinb) silencing cassettes and control pMC161 (pMCG) vector

\begin{tabular}{lllll}
\hline $\begin{array}{l}\text { Silencing } \\
\text { cassette }\end{array}$ & $\begin{array}{l}\text { Number of } \\
\text { explants }\end{array}$ & \begin{tabular}{l} 
Number of selected \\
\cline { 3 - 5 }
\end{tabular} & $\begin{array}{l}\text { Lines (SD) } \\
\text { Plants (SD) }\end{array}$ & $\begin{array}{l}\text { PCR positive } \\
\text { plants / } \\
\text { transformation } \\
\text { efficiency [\%] }\end{array}$ \\
\hline (Pina) & 582 & $17 \pm 0.70$ & $39 \pm 4.94$ & $14 / 2.4$ \\
(Pinb) & 1460 & $3 \pm 1.22$ & $17 \pm 6.94$ & $2 / 0.14$ \\
(Pina)+(Pinb) & 1960 & 0 & 0 & $0 / 0.00$ \\
(pMCG) & 452 & $8 \pm 1.92$ & $14 \pm 3.41$ & $4 / 0.88$ \\
Sum /mean & 4454 & $28 \pm 1.28$ & $70 \pm 5.1$ & $20 / 1.14$ \\
\hline
\end{tabular}

${ }^{a}$ Percentage of initial explants giving rise to PCR positive plants.

most $T_{2}$ lines (9 out of 11) the mean level of transcript was lower than in the parent $\mathrm{T}_{1}$ plant.

As expected, individuals from lines of the $\mathrm{T}_{3}$ generation showed very low transcript levels for both $\mathrm{Sin}$ genes, similar among the plants of the lines (Figure 2c). It was below 0.2 in most of the tested lines as well as their $\mathrm{T}_{2}$ parents. Only in the case of 2E1-4 parents did the levels of Sin expression differ significantly from the levels of $\operatorname{Sin}$ for their progeny.

Data of mean relative transcript level of Sina and Sinb for all tested individuals calculated for $T_{1}, T_{2}$ and $T_{3}$ generations (Figure 3) showed a significant decrease up to 0.1. Independent of the silencing cassette (Pina) or (Pinb), the level of silencing of Sina was similar to the level of silencing of Sinb. Transcripts of both silenced genes were lower by about $40 \%$ in $\mathrm{T}_{1}$ generations, about $70 \%$ to $80 \%$ in $\mathrm{T}_{2}$ generations, and about $90 \%$ in $\mathrm{T}_{3}$.

\section{The secaloindolines and their identification}

Lower transcript level of the Sin genes was correlated with a low or very low level of secaloindoline a (SINA) and secaloindoline b (SINB) (Figure 4).

The protein contents of secaloindoline bands $(<15 \mathrm{kDa})$ was identified by mass spectrometry and compared with a protein sequence database using Mascot search engine (http://www.matrixscience.com/) (Table 2) [2,32-40]. The highest scores of protein identity and number of significant matches $>100$ were obtained for deposited by us in GenBank SINA from triticale cv. Wanad (AGO65289.1); three

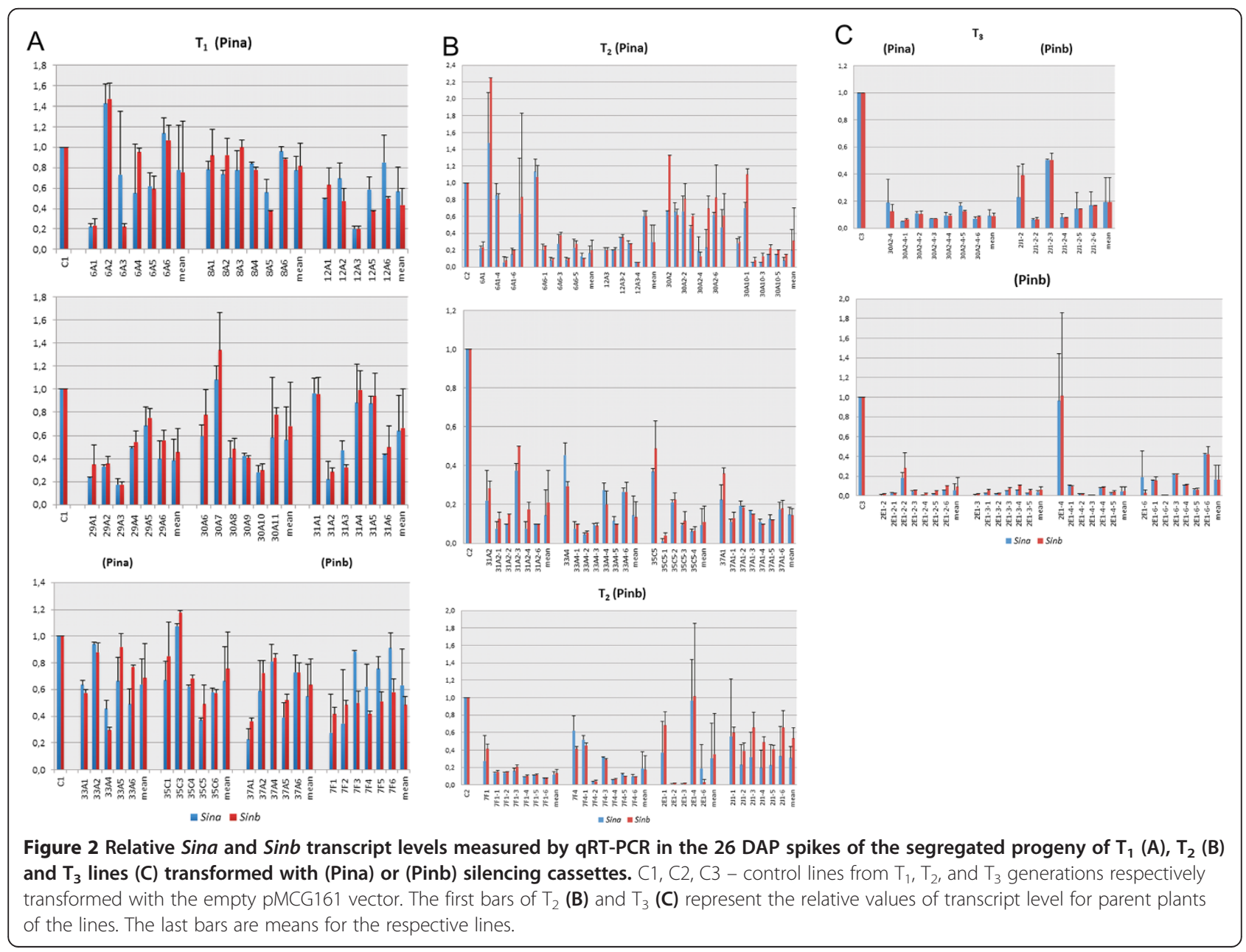




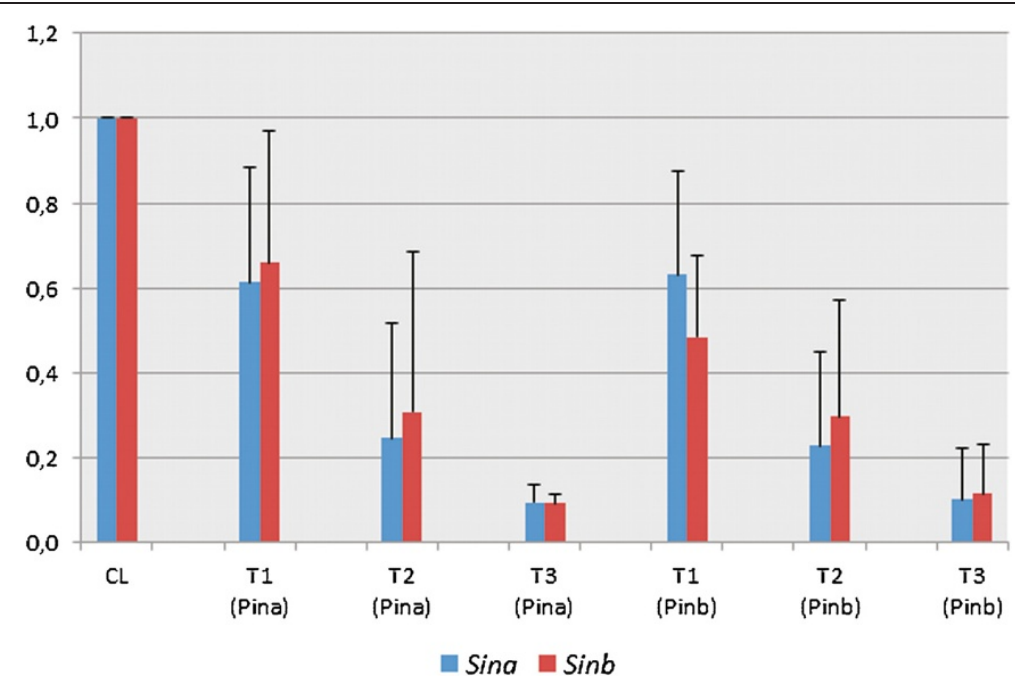

Figure 3 Mean relative transcript level of Sina and Sinb for all tested individuals in $T_{1}, T_{2}$ and $T_{3}$ generations transformed with (Pina) or (Pinb) silencing cassette.

others were PINA from Aegilops sharonensis (ABB52757.1), PINA from Pseudoroegneria spicata (AER62833.1) and PINB from Secale cereale (AAT76523.1). Two more puroindoline-like $\mathrm{b}$ with lower scores and significant matches were from Dasypyrum villosum and Aegilops umbellulata. The rest of proteins were dimeric alphaamylase inhibitors from different species of Triticum and
Aegilops speltoides. According to GeneBank regions 36135 of SINA and 39-137 SINB are named as AAI_SS: Alpha-Amylase Inhibitors (AAIs) and Seed Storage (SS) Protein subfamily. They are composed of cereal-type AAIs and SS proteins [41]. Additionally both proteins contain two more sites: polypeptide binding for dimer interface order and alpha-amylase binding site order. Tryptophan-

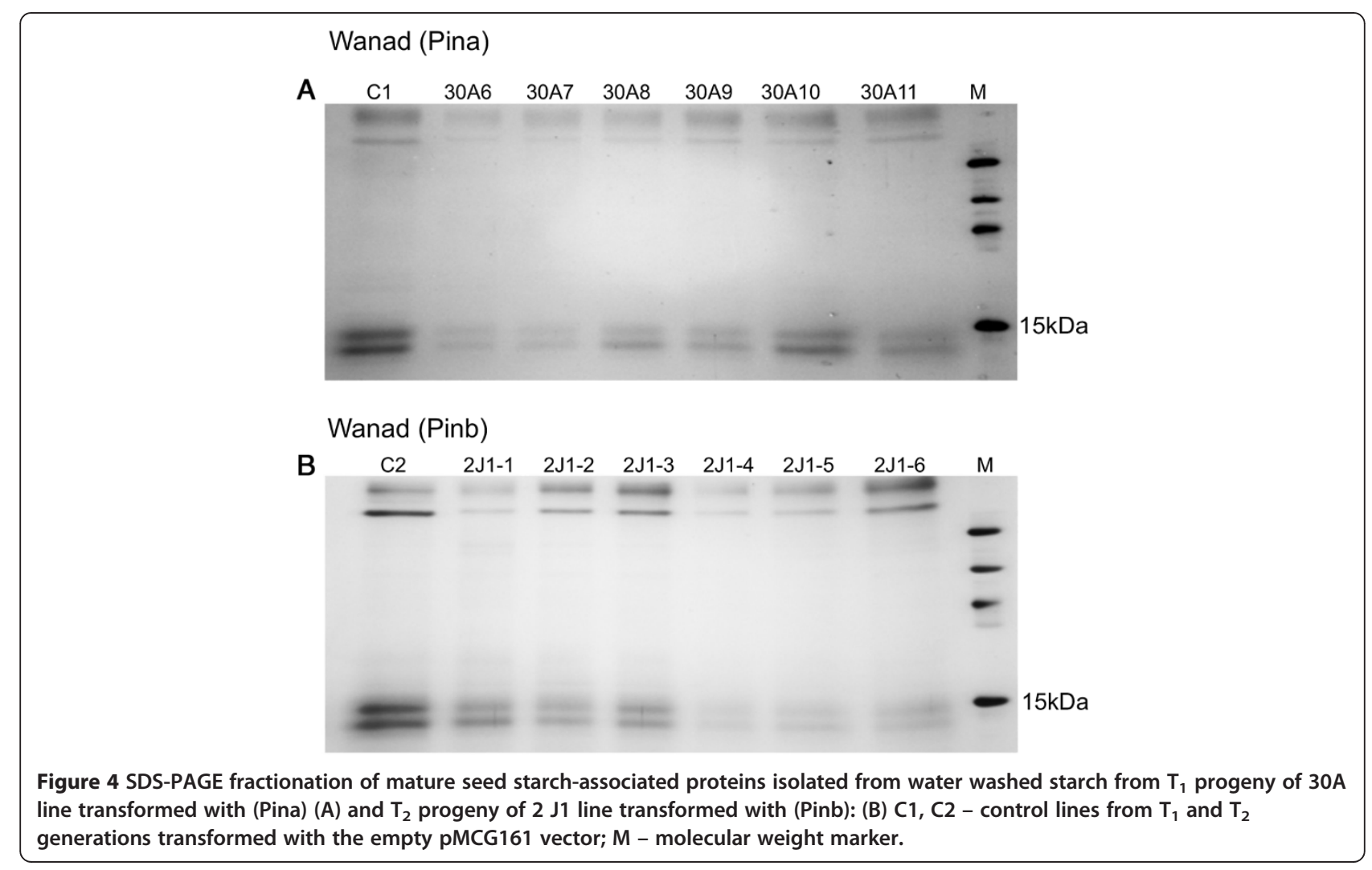


Table 2 Identification of protein contents of secaloindoline bands ( $<15 \mathrm{kDa}$ ) by mass spectrometry and comparison with a protein sequence database using Mascot search engine (http://www.matrixscience.com/); used filters: ("Num. of significant matches">30 AND Score>42)

\begin{tabular}{|c|c|c|c|c|c|c|}
\hline NCBI accession & Score & Mass & $\begin{array}{l}\text { Matches } \\
\text { Pep(sig) }\end{array}$ & Sequences & Description & References \\
\hline gi|515020476 & 15990 & 16803 & 242 & 8 & secaloindoline a [Triticum aestivum $\times$ Secale cereale] & This paper \\
\hline gi|80971579 & 16240 & 14002 & 225 & 4 & puroindoline a [Aegilops sharonensis] & [33] \\
\hline gi|355389782 & 14666 & 17031 & 216 & 4 & puroindoline a [Pseudoroegneria spicata] & [34] \\
\hline gi|50402252 & 3159 & 17220 & 119 & 14 & puroindoline b [Secale cereale] & [2] \\
\hline gi|114215762 & 3369 & 13743 & 59 & 13 & dimeric alpha-amylase inhibitor [Triticum dicoccoides] & [35] \\
\hline gi|123957 & 2337 & 18893 & 50 & 11 & RecName: Full=Alpha-amylase/trypsin inhibitor CM3 & [36] \\
\hline gi|283137474 & 1284 & 17089 & 47 & 9 & dasyoindoline-b [Dasypyrum villosum] & [unpublished] \\
\hline gi|114215784 & 2683 & 13771 & 45 & 12 & dimeric alpha-amylase inhibitor [Triticum dicoccoides] & [35] \\
\hline gi|227809278 & 2498 & 15588 & 41 & 11 & dimeric alpha-amylase inhibitor [Triticum timopheevii subsp. armeniacum] & {$[37]$} \\
\hline gi|123958 & 1191 & 16399 & 41 & 10 & RecName: Full=Alpha-amylase/trypsin inhibitor CM16 & [38] \\
\hline gi|114215854 & 2136 & 13948 & 38 & 9 & dimeric alpha-amylase inhibitor [Aegilops speltoides] & {$[35]$} \\
\hline gi|65993872 & 2248 & 15578 & 37 & 10 & dimeric alpha-amylase inhibitor [Triticum aestivum] & [39] \\
\hline gi|82659349 & 741 & 17357 & 34 & 8 & puroindoline-b [Aegilops umbellulata] & [32] \\
\hline gi|114215874 & 1655 & 13981 & 33 & 7 & dimeric alpha-amylase inhibitor [Aegilops speltoides] & {$[35]$} \\
\hline gi|227809121 & 1690 & 15555 & 31 & 8 & dimeric alpha-amylase inhibitor [Triticum dicoccoides] & {$[37]$} \\
\hline gi|283465827 & 1716 & 13566 & 31 & 7 & putative alpha-amylase inhibitor CM2, partial [Triticum aestivum] & [40] \\
\hline
\end{tabular}

rich domain of SINA is FPVTWQWWKWWKG and differ from wild-type of Pina-D1a allele protein of T. aestivum by one amino acid ( $\mathrm{R}$ instead of $\mathrm{Q}=$ arginine is changed to glutamine). The same domain of PINB is FPVTWPTRWWKG and differ from wild-type PINA by one amino acid ( $\mathrm{R}$ instead of $\mathrm{K}=$ arginine is changed to lysine).

Comparison of amino acid sequences of SINA (AGO65289.1) and SINB (AGO65290.1) from triticale cv. Wanad with PINA, PINB from $T$. aestivum Chinese Spring and other puroindoline-like proteins listed in Table 2 is presented in Additional file 3. The highest percent identity (97.3\% and $98.6 \%$ ) was between SINA and SINB from cv. Wanad and SINA and SINB from Secale cereale (cv. Galma and cv. Imperial respectively). Lower data, $91.2 \%$ and $90.5 \%$ identity were between SINA and SINB from cv. Wanad and "wild type alleles" proteins PINA and PINB from T. aestivum cv. Chinese Spring.

\section{The hardness index and related traits}

The grain hardness index and other characteristics, such as weight, moisture, and seed diameter, were determined using the Single Kernel Characterization System in two experiments. In the first one, $6 \mathrm{~T}_{1}$ plants transformed with (Pina) and $6 \mathrm{~T}_{1} / \mathrm{T}_{2}$ plants transformed with (Pinb) were compared with control plants (not shown). The hardness index ranged from 36.14 to 55.65 in silenced plants and from 44.4 to 49.1 in controls. Correlation coefficient between hardness and transcript level for Sina was 0.35 and for $\operatorname{Sinb}$ was 0.52. Hardness index was positively correlated with transcript level of Sin genes.

In the second one, 24 progeny plants from 12 silenced with (Pina) $\mathrm{T}_{2} / \mathrm{T}_{3}$ lines and 17 progeny plants from 7 silenced with (Pinb) $T_{2} / T_{3}$ lines were tested. Means for these data including total seed protein content are shown in Table 3. The hardness index ranged from 21.89 to 49.25 in silenced plants and from 37.47 to 43.48 in controls. The mean values of the hardness index were lower in two groups of transgenic lines showing significantly decreased transcript levels. The hardness index in control, not silenced lines was 40.69, in lines silenced with (Pina) it was 37.59, and in lines silenced with (Pinb) it was 34.70. The mean relative transcript levels of Sina and $\operatorname{Sin} b$ in the same group of lines were 1.00 and 1.00, 0.31 and $0.39,0.12$ and 0.13 , respectively. Additionally, the total seed protein content of silenced lines was significantly lower compared with control lines. It was $14.62 \%$ for control and $13.70 \%$ or lower for silenced lines. There were no differences in weight or diameter of the seeds between the silenced lines and controls. The correlation coefficient between hardness and transcript level in the second group of plants for Sina was 0.06 and for $\operatorname{Sin} b$ was 0.11 . Hardness index was weakly positively correlated with transcript level of $\operatorname{Sin}$ genes.

\section{Discussion}

Alignment of newly isolated Sina and $\operatorname{Sin} b$ from cv. Wanad with the few known from GenBank Sin alleles of 
Table 3 Mean values of the grain hardness index and other characteristics (weight, moisture, diameter) determined using the Single Kernel Characterization System and total protein content in Control and lines silenced with (Pina), (Pinb)

\begin{tabular}{|c|c|c|c|c|c|c|}
\hline Lines & Sina (SD) & $\operatorname{Sinb}(\mathrm{SD})$ & Hardness (SD) & Weight [mg] (SD) & Diameter [mm] (SD & Protein (\%) (SD) \\
\hline Control & $1.00 \pm 0.00$ & $1.00 \pm 0.00$ & $40.69 \pm 13.21$ & $48.68 \pm 6.06$ & $3.13 \pm 0.24$ & $14.62 \pm 0.25$ \\
\hline (Pina) & $0.31 \pm 0.04$ & $0.39 \pm 0.04$ & $37.59 \pm 12.54$ & $49.63 \pm 6.48$ & $3.13 \pm 0.26$ & $13.70 \pm 0.6$ \\
\hline (Pinb) & $0.12 \pm 0.01$ & $0.13 \pm 0.01$ & $34.70 \pm 11.98$ & $47.86 \pm 6.80$ & $3.05 \pm 0.27$ & $13.64 \pm 0.82$ \\
\hline
\end{tabular}

$S$. cereale revealed a few differences including single nucleotide substitutions and codon deletion or insertion. This comparison also showed that Sin alleles are more variable among themselves than Pin alleles, which frequently differ in only one nucleotide [19,21]. In wheat even single point mutation leading to a small differences in amino acid sequence might have an immense impact on wheat hardness [42-44]. It might change structure of the protein including conformation of tryptophan-rich domain, what have an impact on lipid-binding properties and wheat kernel hardness [reviewed in [45]. Otherwise, until now no relationship between polymorphism of Sin genes and grain hardness in rye or triticale has been reported [13,14,23]. However discrimination of soft and hard genotypes of triticale, which correlated with the level of starch granule-associated friabilin was presented [14]. Experimental, wild-type Wanad cultivar was classified as soft/medium-soft phenotype, accumulating high levels of SIN proteins.

Wheat Pina-D1a (DQ363911.1) and Pinb-D1a (DQ363913.1) alleles showed 95\% and 93\% homology with Sina and Sinb coding sequences of the tested triticale cultivar. Each ortholog contained several long, exceeding 21 nt $100 \%$ homologous fragments. This feature allowed us to apply the same, hpRNA type of silencing cassette, which has already been successfully used for silencing of Pin genes in wheat [22] to silence $\operatorname{Sin}$ genes in triticale. (Pina) contained the whole coding sequence of Pina-D1a in sense and antisense orientation; (Pinb) contained the respective Pinb-D1a sequences, both 447 bp long. According to the process of RNAi silencing by hpRNA constructs, short interfering RNA (siRNA), which could repress the expression of the target genes, are 21, 22 or 24 bp long (reviewed in $[46,47]$ ). The degradation of the expressed silencing construct might lead to the formation of several different siRNA, which could repress expression of the target genes.

High coding sequence homology of Sin with their orthologous Pin genes was coupled with high, more than $90 \%$ amino acid homology. Products of Pin, puroindoline a and puroindoline b [22], and products of Sin alleles, secaloindoline a and secaloindoline b, were abundant in wild type cultivars, which gave a good opportunity to test silencing of the genes by RNAi.
Temporal expression patterns of both $\operatorname{Sin}$ genes in wild type plants of triticale cv Wanad during kernel development were parallel, with slightly lower relative values of the transcript for Sinb and with the peak at 26 DAP for both genes. This peak of transcript accumulation indicated the best phase of kernel development to measure the level of gene silencing in silenced lines. The highest relative values of Sina was about 55 times higher and for Sinb 43 times higher compared with the first measurement at 8 DAP. Similar expression profiles were observed for Pina and Pinb in two wheat cultivars [22]. These data are also consistent with starch and gluten accumulation patterns $[48,49]$ as it was presented by Pauly et al. [45].

Fourteen transgenic lines transformed with the silencing cassette for Sina silencing and two for Sinb were selected after Agrobacterium-mediated transformation. As was already documented in the case of gene silencing [28] as well as transgene expression [29,30], this method should be the method of choice. Segregation of silencing was observed among progeny of all tested $\mathrm{T}_{1}$ lines documenting high efficiency of the RNAi silencing process. Similar to silencing of Pin genes in wheat [22], both Sin genes were silenced at a similar level independent of the silencing cassette used. This feature is not explained by long RNAi trigger size and high homology of Sina and Sinb. The putative hairpin precursors (hpRNA) from both silencing cassettes did not form short interfering RNA (siRNA) 21-24 nt long, which could repress the expression of both genes.

Selection of silent siblings up to the fourth generation resulted in a uniform level of silencing among $\mathrm{T}_{3}$ progeny of most of the sublines. The level of silencing of Sin genes measured by qRT-PCR was up to $99 \%$, and was even several percent lower than in the case of Pin genes in wheat [22]. The reported expression of other silent genes in wheat relative to the control ranged from $10 \%$ to $80 \%$ [25-27]. Comparison of expression to other alleles/mutants of Sin in rye, Secale cereale or triticale genotypes was impossible because of the lack of such studies. This high level of silencing of Sin and Pin genes might be the result of the main advantage of RNAi technology, which is the possibility to silence all homologous or orthologous genes as well as additional copies of the genes [24,50]. As reported by Wilkinson et al. [51], 
additional variants of Pinb existed in part as a homologous series on the long arm of chromosome 7A. These variants, renamed as Pinb-2 series as well as novel variants found were mapped on chromosomes 7D, 7B and 7A [52,53]. Expression of these variants and their impact on grain texture was also reported [54,55]. Triticale shares with wheat two of three genomes, A and B, where all the orthologs to Sina and Sinb might be silenced. Simultaneous silencing of orthologs or homologs of Sin might determine that the level of RNAi silencing would always exceed the decrease of transcript in mutant or even in lack-of-function genotypes.

Silencing of Sin genes resulted in low or almost lack of products, secaloindoline $\mathrm{a}$ and secaloindoline $\mathrm{b}$. The most unexpected result of Sin silencing was the lack of correlation between low expression level of silent genes and increased grain hardness as was observed in wheat [22]. Moreover, correlation coefficients indicated a weak positive relationship between decrease of the transcripts and decrease of the hardness. Taking into account that generally there is no grain hardness variation in rye, our results may suggest that grain hardness in triticale is not related to Sin genes and other factors might control this trait in both mentioned species. However, without knowledge about allelic variations of $\operatorname{Sin}$ genes in both rye and triticale we cannot draw clear conclusions. The hardness index was measured by the SKCS method, which is the current reference method for determination of kernel texture for wheat [56]. The same method was used for grain hardness measurement and classification in 171 triticale lines [14]. Good correlation was also been found between SKCS and PSI (particle size index) method of hardness measurement in barley [57]. The values ranged from 22 to 56 in the silent triticale lines and from 37 to 49 in the control, and the mean values were lower in the silent ones, proving increase of softness. Smaller sample sizes used in our experiment might give some skewed results, however the SKCS data indicate general trend of hardness. Decrease of expression of $\mathrm{Sin}$ genes was correlated with lower secaloindoline a and secaloindoline b content, influencing the total seed protein content, which was significantly lower compared with control lines. Opposite to triticale, the total seed protein content in silenced lines of wheat was the same as in controls (not published yet). This might indicate that the lack of puroindolines in wheat was offset by other proteins and in triticale not. The range of grain hardness measured using SKCS for 171 hexaploid triticale lines ranged from 8.6 to 84.9 [14]. Opposite to our results, the authors reported that all soft lines contained a high level of friabilin. Consistent with the function of grain hardness Pin genes in wheat was also the role of Hin genes in barley. The mutation in these genes resulted in an increase in grain hardness [58]. However, in another report low variation in grain hardness of a broad range of barley breeding lines and commercial varieties was documented [57].

The identities of secaloindoline $a$ and secaloindoline $b$ bands on the gel were proved by mass spectrometry and comparison with a protein sequence database using Mascot search engine. Both SINA and SINB from triticale cv. Wanad showed the highest percent of identity with SINA and SINB from soft grain cultivars of S. cereale, what might suggest their functionality. The rest of identified puroindolines belong to different species of Triticeae or were identified as cereal-type AAIs and SS protein subfamily - regions existing in the SIN proteins. They are described as mainly present in the seeds of a variety of plants. AAIs play an important role in the natural defenses of plants [41]. Both SIN proteins contain in these regions tryptophan-rich domains, which are highly similar (differ only one amino acid) to regions coded by wild-type of Pina-D1a (PuroA) and Pinb-D1a (PuroB). The 13-mer of PuroA constitutes the antimicrobial active center of puroindoline a [59]. The corresponding, 12-mer tryptophan-rich domain in puroindoline b was relatively antimicrobially inactive compared to PuroA [60]. It is probable that these highly conserved regions of SIN proteins express the same properties. These data are also consistent with the hypothesis, that positive selection at the Pina region of the Hardness locus in the tribe Triticeae was congruent with its role as plant defense gene [32]. Besides the effect of puroindolines on the grain hardness determining technological end-uses and their role in plant defense some new biological functions are suggested [45,61]. The results of proteome analysis of soft and hard nearisogenic wheat lines revealed their possible involvement in the storage protein folding machinery affecting the development of wheat endosperm and the formation of the protein matrix [61].

One of the important advantages of RNAi type of silent lines obtained in the process of stable transformation is inheritance of the traits. The $\mathrm{T}_{4}$ kernels from the $\mathrm{T}_{3}$ generation of triticale plants, which showed an almost equal level of silencing among progeny, might be treated as homozygotes. These selected lines gave a good opportunity for further research concerning other possible functions of $\operatorname{Sin}$ genes including their influence on the quality, their role in biotic stresses, polar lipids and in the storage protein folding machinery.

\section{Conclusions}

The general effect of RNAi-based silencing of Sin genes in hexaploid triticale concerning significant decrease of their transcripts and very low level of both secaloindoline proteins were consistent with that obtained for silencing of Pin genes in hexaploid wheat. The unexpected differences 
occurred on phenotypic level. Silencing of Sina and Sinb did not determine grain hardness contrary to their orthologs Pina and Pinb in wheat. Another difference was the total seed protein content in silent lines, which was significantly lower in triticale and similar to control lines in wheat. Since both secaloindoline proteins are present in wild-type, medium-soft phenotype of cv. Wanad and grain hardness remains unchanged in silenced lines with strongly decreased level of both SIN proteins we propose that their biological function does not affect grain texture. Selected lines of triticale and wheat showing siRNA-mediated allelespecific silencing of both $\operatorname{Sin}$ and Pin genes might be useful in further research.

\section{Methods}

\section{Plant material}

Donor plants of the Polish spring triticale ( $x$ Triticosecale Wittmack) cultivar Wanad were grown under controlled environmental conditions with $18 / 15^{\circ} \mathrm{C}$ day / night temperatures and $16 \mathrm{~h}$ photoperiod. The light intensity was $350 \mu \mathrm{mol} \cdot \mathrm{s}^{-1} \cdot \mathrm{m}^{-2}$. Six seeds of each line were seeded into $17 \mathrm{~cm} \times 23 \mathrm{~cm} \times 17 \mathrm{~cm}$ pots filled with Aura substrate for sowing and bed out (Hollas sp. $\mathrm{z}$ o.o.). Plants were irrigated twice a week and fertilized ones a week with multicomponent soil fertilizer florovit (www.florovit.pl) according to producer instructions.

\section{Vector construction and Agrobacterium-mediated transformation}

The hpRNA cassettes for silencing of Sina and Sinb genes were constructed using the RNAi vector pMCG161 (http:// www.chromdb.org/rnai/pMCG161.html). The T-DNA of this vector contained the selection gene bar under control of the Ubi1 intron promoter and the silencing cassette with two restriction sites separated by a rice waxy intron driven by the CaMV $35 \mathrm{~S}$ promoter and terminated with OCS3' terminator. Two hpRNA cassettes were constructed by cloning the full coding sequences of Pina or Pinb genes in a sense and antisense orientation as described by Gasparis et al. [22]. The $447 \mathrm{bp}$ fragments of both genes were amplified using DNA isolated from T. aestivum cv Kontesa. The following primers containing appropriate restriction sites for cloning to the pMCG161 vector were used: for Pina (forward) 5'-TTCGGACCGACTAGTATGAAGGCCCTC TTCCTCATA-3', (reverse) 5'-TTCCTAGGCCCGGGT CACCAGTAATAGCCAATAGTG-3'; for Pinb (forward) 5'-TTCGGACCGACTAGTATGAAGACCTTATTCCTCC TA-3', (reverse) 5'-TTCCTAGGCCCGGGAGTAATAGC CACTAGGGAACTT-3'. The resulting vectors were pMCG (Pina) for silencing of the Sina gene, pMCG (Pinb) for silencing the Sinb gene, and the empty pMCG, which is the pMCG161 vector without a silencing cassette. They were electroporated to the Agrobacterium tumefaciens strain AGL1 and used either for independent transformation or co-transformation of cr Wanad triticale. The transformation experiments were performed based on our previously described protocols [31].

\section{PCR amplification}

Genomic DNA was isolated from young leaves according to the modified CTAB procedure [62]. PCR reactions were carried out in a $25 \mu \mathrm{l}$ reaction mixture containing $1 \times$ PCR buffer, $2 \mathrm{mM}$ of $\mathrm{MgCl}_{2}, 0.2 \mathrm{mM}$ of dNTPs, $0.4 \mu \mathrm{M}$ of each primer, $1 \mathrm{U}$ of Platinum Taq polymerase (Life Technologies), and 120 ng of template DNA. Integration of the silencing cassettes in transgenic plants was examined by amplification of different fragments of T-DNA with five pairs of primers. The pM1,2 and pM3,4 oligos primed the amplification of $902 \mathrm{bp}$ and 829 bp fragments of sense and antisense inserts respectively. Three pairs of qOCS oligos primed the amplification of the OCS3' terminator fragments of $171 \mathrm{bp}$ (qOCS1,2), 171 bp (qOCS3,4), and 182 bp (qOCS5,6). The sequences of primers and PCR conditions were as described previously [22].

The full coding sequence of the Sina gene was amplified using two pairs of specific primers. The first pair were Seca_F (forward) 5'-GGTGTGGCCTCATCTCATCT-3' and Wpa_R (reverse) 5'-ACCTGGCAGTGGTGGAAATG GT-3'. The second pair were Wpa_F (forward) 5'CTTCCACCATTTCCACCACTGCCAGGT-3' and Seca_R (reverse) 5'-AAATGGAAGCTACATCACCAGT-3'. The Seca primers were described previously by Massa and Morris [32] and Wpa primers were designed by us using the program Primer3plus. The full coding sequence of the Sinb gene was amplified using primers designed by Lillemo et al. [63]: forward 5'-CATCTATTCATCTCCACCTGC-3', reverse $5^{\prime}$-GTGACAGTTTATTAGCTAGTC-3'. Annealing temperature for each pair of primers was $58^{\circ} \mathrm{C}$ and the remaining amplification conditions were as described above.

\section{RNA isolation and CDNA synthesis}

Total RNA was isolated from immature kernels 8, 14, 20, 26 and 32 days after pollination (DAP) using a modified procedure of Prescott and Martin [64]. An additional extraction step with TRI-Reagent (Life Technologies) was performed according to the manufacturer's protocol. After extraction RNA samples were treated with DNaseI, RNase Free (Roche) to remove the residual genomic DNA. cDNA was synthesized from $1 \mu \mathrm{g}$ of RNA using RevertAid First Strand cDNA Synthesis Kit (Thermo Scientific).

\section{Quantitative RT-PCR analysis}

26 DAP samples were chosen for qPCR analysis of the relative expression level of Sina and Sinb genes in silenced transgenic plants. The sequences of the primers were as follows: for Sina, qPinA1 (forward) 5 -CTCA TAGGACTGCTTGCTCTGGTAG-3', qPinA2 (reverse) 
5'-GATTGACCCCTGGATGATGTTG-3'; for Sinb, qPinB1 (forward) 5' -AATGAAGTTGGCGGAGGAGGT G-3', qPinB2 (reverse) 5'-ATACCTCACCTCGCCAAA TGCC-3'; and for 18S rRNA, 18S F (forward) 5'GTGACGGGTGACGGAGAATT-3', 18S R (reverse) 5' GACACTAATGCGCCCGGTAT-3' [65]. The reaction was carried out in a $15 \mu \mathrm{l}$ mixture containing $1 \mathrm{x}$ Sso Fast EvaGreen Supermix (Bio-Rad), $0.4 \mu \mathrm{M}$ of each primer, and $1 \mu \mathrm{l}$ of the template cDNA. The following temperature profile was used: an initial denaturation step of $95^{\circ} \mathrm{C}$ for $2 \mathrm{~min}$, amplification at $95^{\circ} \mathrm{C}$ for $25 \mathrm{~s}, 58^{\circ} \mathrm{C}$ for $25 \mathrm{~s}$, and $72^{\circ} \mathrm{C}$ for $25 \mathrm{~s}$, and a melting curve profile of $72-95^{\circ} \mathrm{C}$ with the temperature rising $1^{\circ} \mathrm{C}$ at each step and continuous fluorescence measurement. The relative expression level of Sina and Sinb was calculated according to the $\Delta \Delta \mathrm{Ct}$ method using $18 \mathrm{~S}$ rRNA as a normalizer. The values of the three replicates of each sample were used for the calculation. The line transformed with the empty vector pMCG161 was designated as a calibrator sample with its expression value set to 1 . The normalized values of the tested samples are expressed as $\mathrm{x}$-fold of 1 .

\section{Extraction of proteins and SDS-PAGE analysis}

Secaloindoline proteins were extracted from the waterwashed starch fraction of endosperm using the method of Bettge et al. [66] with modifications according to Chang et al. [67]. For each sample an equal amount of starch was used for extraction of proteins.

The SDS-PAGE buffers and gels were prepared according to Laemmli [68]. The stacking gels were $5 \% \mathrm{~T}, 2.6 \% \mathrm{C}$, and the resolving gels were $15 \% \mathrm{~T}$, $2.6 \% \mathrm{C}, 1.5 \mathrm{~mm}$ thick. $18 \times 16 \mathrm{~cm}$ gels were resolved in a Hoeffer SE 660 apparatus at $25 \mathrm{~mA}$ until the dye reached the bottom edge of the gel. After electrophoresis the gels were silver stained using the protocol of Gromova and Celis [69].

\section{Identification of protein contents of the sample}

SDS PAGE bands $(<15 \mathrm{kDa})$ of SINA and SINB were cut off from the gel and prepared for qualitative mass spectrometry analysis (http://mslab-ibb.pl/en/uslugi). A procedure includes following steps: reduction and alkylation of protein disulfide bonds, followed by tryptic digestion to obtain peptide mixture, liquid chromatography (LC) separation of a sample, MS measurement of peptides and their fragmentation spectra (tandem mass spectrometry) and searching of acquired spectra against a protein sequence database of choice (NCBI, UniProt or customer-supplied database) using Mascot search engine (http://www. matrixscience.com/), followed by validation and formatting of results.

\section{SKCS, total seed protein and statistical analysis}

Grain hardness, weight, moisture, and diameter of kernels were analyzed using the Single-Kernel Characterization System 4100 (Perten Instruments). Each sample contained 35 or 50 kernels and all parameters were calculated for each individual kernel. In total 47 individual plants from T2 and T3 generation were tested: 24 from 12 lines silenced by Pina cassette; 17 from 7 lines silenced by Pinb cassette and 6 from 3 lines transformed with the PMCG without silencing cassette. The grain protein content was determined via near-infrared transmission using a grain analyzer for the same lines (Infratec 1225).

Statistical analysis was performed using Statistica software (StatSoft). The correlation coefficient between the expression level of Sin genes and the grain hardness was calculated in Microsoft Excel.

\section{Additional files}

Additional file 1: Figure S1. Alignment of the $\operatorname{Sin} a$ and $\operatorname{Sin} b$ sequences of cv. Wanad with others deposited in GenBank by DNASTAR Lasergene software.

Additional file 2: Figure S2. Alignment of the Sina and $\operatorname{Sin} b$ sequences of $\mathrm{CV}$. Wanad with Pina and Pinb by DNASTAR Lasergene software.

Additional file 3: Figure S3. Alignment of the SINA and SINB amino acid sequences of $\mathrm{cv}$. Wanad with others puroindoline-like proteins find by Mascot (Table 3).

\section{Competing interests}

The authors declare that they have no competing interests.

\section{Authors' contributions}

SG carried out most of the experiments: vector construction, genetic transformation, selection and analysis of plants; WO coordinated some experiments (vector construction, analysis of expression) and took part in discussion of the project; ANO have made substantial contributions to conception and design, analysis and interpretation and wrote the manuscript. All authors read and approved the final manuscript.

\section{Acknowledgements}

The authors thank Prof. Stanislaw Grundas for carrying out the SKCS measurements. This research was supported by the Polish Ministry of Science and Higher Education, grant N302 013 31/1517 and National Science Centre, grant UMO-2011/03/B/NZ9/01383.

\section{Author details}

${ }^{1}$ Department of Functional Genetics, Plant Breeding and Acclimatization Institute - National Research Institute, Radzikow, 05-870 Blonie, Poland. ${ }^{2}$ Department of Genetic Engineering, Plant Breeding and Acclimatization Institute - National Research Institute, Radzikow, 05-870 Blonie, Poland.

Received: 9 October 2013 Accepted: 20 November 2013

Published: 26 November 2013

\section{References}

1. Dubreil L, Meliande S, Chiron H, Compoint J-P, Quillien L, Branlard G, Marion D: Effect of puroindolines on the bread making properties of wheat flour. Cereal Chem 1998, 75:222-229.

2. Igrejas G, Gaborit T, Oury F-X, Chiron H, Marion D, Branlard G: Genetic and environmental effects on puroindoline-a and puroindoline-b content and their relationship to technological properties in French bread wheats. J Cereal Sci 2001, 34:37-47.

3. Jolly CJ, Rahman S, Kortt AA, Higgins TJV: Characterization of the wheat Mr 15000 "grain-softness protein" and analysis of the relationship 
between its accumulation in the whole seed and grain softness. Theor App/ Genet 1993, 86:589-597.

4. Gautier M-F, Aleman M-E, Guirao A, Marion D, Joudrier P: Triticum aestivum puroindolines, two basic cysteine-rich seed proteins: cDNA sequence analysis and developmental gene expression. Plant Mol Biol 1994, 25:43-57.

5. Morris CF, Greenblatt GA, Bettge AD, Malkawi HI: Isolation and characterization of multiple forms of friabilin. J Cereal Sci 1994, 21:167-174.

6. Blochet J-E, Chevalier C, Forest E, Pebay-Peyroula E, Gautier MF, Joudrier P, Pezolet M, Marion D: Complete amino acid sequence of puroindoline, a new basic and cysteine-rich protein with a unique tryptophan-rich domain, isolated from wheat endosperm by Triton X-114 phase partitioning. FEBS Lett 1993, 329:336-340.

7. Dubreil L, Compoint JP, Marion D: Interaction of puroindoline with wheat flour polar lipids determines their foaming properties. J Agric Food Chem 1997, 45:108-116.

8. Dubreil L, Gaborit T, Bouchet B, Gallant DJ, Broekaert WF, Quillien L, Marion D: Spatial and temporal distribution of the major isoforms of puroindolines (puroindoline-a and puroindoline-b) and non-specific lipid transfer protein (ns-LTP1e1) of Triticum aestivum seeds. Relationships with their in vitro antifungal properties. Plant Sci 1998, 138:121-135.

9. Krishnamurthy K, Giroux MJ: Expression of wheat puroindoline genes in transgenic rice enhances grain softness. Nat Biotechnol 2001, 19:162-166.

10. Capparelli R, Amoroso MG, Palumbo D, lannaccone M, Faleri C, Cresti M: Two plant puroindolines colocalize in wheat seed and in vitro synergistically fight against pathogens. Plant Mol Biol 2005, 58:857-867.

11. Evrard A, Meynard D, Guiderdoni E, Joudrier P, Gautier M-F: The promoter of the wheat puroindoline-a gene (PinA) exhibits a more complex pattern of activity than that of the PinB gene and is induced by wounding and pathogen attack in rice. Planta 2007, 255:287-300.

12. Morrison WR, Greenwell P, Law CN, Sulaiman BD: Occurrence of friabilin, a low molecular weight protein associated with grain softness, on starch granules isolated from some wheats and related species. J Cereal Sci 1992, 15:143-149.

13. Simeone $M C$, Lafiandra $\mathrm{D}$ : Isolation and characterization of friabilin genes in rye. J Cereal Sci 2005, 41:115-122.

14. Li G, He Z, Pena RJ, Xia X, Lillemo M, Qixin S: Identification of novel secaloindoline-a and secaloindoline-b alleles in CIMMYT hexaploid triticale lines. J Cereal Sci 2006, 43:378-386

15. Williams PC, Sobering DC: Attempts at standardization of hardness testing of wheat. I. The grinding/sieving (particle size index) method. Cereal Foods World 1986, 31:359. pp 362-364.

16. Gautier M-F, Cosson P, Guirao A, Alary R, Joudrier P: Puroindoline genes are highly conserved in diploid ancestor wheats and related species but absent in tetraploid Triticum species. Plant Sci 2000, 153:81-91.

17. Sourdille P, Perretant MR, Charmet G, Leroy P, Gautier M-F, Jourdier P, Nelson JC, Sorrels MC, Bernard M: Linkage between RFLP markers and genes affecting kernel hardness in wheat. Theor Appl Genet 1996, 93:580-586.

18. Giroux MJ, Morris CF: Wheat grain hardness results from highly conserved mutations in the friabilin components puroindoline a and b. Proc Natl Acad Sci USA 1998, 95:6262-6266.

19. Bhave M, Morris CF: Molecular genetics of puroindolines and related genes: allelic diversity in wheat and other grasses. Plant Mol Biol 2008, 66:205-219.

20. Bhave M, Morris CF: Molecular genetics of puroindolines and related genes: regulation of expression, membrane binding properties and applications. Plant Mol Biol 2008, 66:221-231.

21. Nadolska-Orczyk A, Gasparis S, Orczyk W: The determinants of grain texture in cereals. J Appl Genet 2009, 50:185-197.

22. Gasparis S, Orczyk W, Zalewski W, Nadolska-Orczyk A: The RNA-mediated silencing of one of the Pin genes in allohexaploid wheat simultaneously decreases the expression of the other, and increases grain hardness. J Exp Bot 2011, 62:4025-4036. Doi: 10.1093/jxb/err103.

23. Ramirez A, Perez GT, Ribotta PD, Leon AE: The occurrence of friabilins in triticale and their relationship with grain hardness and baking quality. J Agric Food Chem 2003, 51:7176-7181.

24. Travella S, Klimm TE, Keller B: RNA interference-based gene silencing as an efficient tool for functional genomics in hexaploid bread wheat. Plant Physiol 2006, 142:6-20.

25. Fu D, Uauy C, Blechl A, Dubcovsky J: RNA interference for wheat functional gene analysis. Transgenic Res 2007, 16:689-701.
26. Gil-Humanes J, Piston F, Hernando A, Alvarez JB, Shewry PR, Barro F: Silencing of Y-gliadins by RNA interference (RNAi) in bread wheat. J Cereal Sci 2008, 48:565-568.

27. Nemeth C, Freeman J, Jones HD, Sparks C, Pellny TK, Wilkinson MD, Dunwell J, Andersson AA, Aman P, Guillon F, Saulnier L, Mitchell RA, Shewry PR: Down-regulation of the CSLF6 gene results in decreased $(1,3 ; 1,4)$-beta-D-glucan in endosperm of wheat. Plant Physiol 2010, 152:1209-1218.

28. Zalewski W, Orczyk W, Gasparis S, Nadolska-Orczyk A: HvCKX2 gene silencing by biolistic or Agrobacterium-mediated transformation in barley leads to different phenotypes. BMC Plant Biol 2012, 12:206. http://www.biomedcentral.com/14712229/12/206.

29. Dai S, Zheng P, Marmey P, Zhang S, Tian W, Chen S, Beachy RN, Fauquet C: Comparative analysis of transgenic rice plants obtained by Agrobacterium-mediated transformation and particle bombardment. Mol Breeding 2001, 7:25-33.

30. Travella S, Ross SM, Harden J, Everett C, Snape JW, Harwood WA: A comparison of transgenic barley lines produced by particle bombardment and Agrobacterium-mediated techniques. Plant Cell Rep 2005, 23:780-789.

31. Nadolska-Orczyk A, Przetakiewicz A, Kopera K, Binka A, Orczyk W: Efficient method of Agrobacterium-mediated transformation for triticale (x Triticosecale Wittmack). J Plant Growth Regul 2005, 24:2-10.

32. Massa AN, Morris CF: Molecular evolution of the puroindoline-a, puroindoline-b, and grain softness protein-1 genes in the tribe Triticeae. J Mol Evol 2006, 63:526-536.

33. Chen M, Wilkinson M, Tosi P, He G, Shewry P: Novel puroindoline and grain softness protein alleles in Aegilops species with the C, D, S, M and U genomes. Theor App/ Genet 2005, 111:1159-1166.

34. Escobar JS, Scornavacca C, Cenci A, Guilhaumon C, Santoni S, Douzery EJP, Ranwez V, Glémin S, David J: Multigenic phylogeny and analysis of tree incongruences in Triticeae (Poaceae). BMC Evol Biol 2011, 11:181.

35. Wang JR, Zhang L, Wei YM, Yan ZH, Baum BR, Nevo E, Zheng YL: Sequence polymorphisms and relationships of dimeric alpha-amylase inhibitor genes in the B genomes of Triticum and S genomes of Aegilops. Plant Sci 2007, 173:1-11.

36. Shewry PR, Lafiandra D, Salcedo G, Aragoncillo C, Garcia-Olmedo F, Lew EJL, Dietler MD, Kasarda DD: N-terminal amino acid sequence of chloroform/methanol-soluble proteins and albumins from endosperm of wheat, barley and related species. FEBS Lett 1984, 175:359-363.

37. Wang J-R, Pu Z-E, Lan X-J, Baum BR, Yan Z-H, Zheng Y-L, Wei L-M: Phylogenetic analysis of the dimeric alpha-amylase inhibitor sequences from an orthologous region in 21 different genomes of the tribe Triticeae (Poaceae). Biochem Syst Ecol 2010, 38:708-714.

38. Gautier MF, Alary R, Joudrier P: Cloning and characterization of a cDNA encoding the wheat (Triticum durum Desf.) CM16 protein. Plant Mol Biol 1990, 14:313-322.

39. Wang J-R, Yan Z-H, Wei Y-M, Nevo E, Baum BR, Zheng Y-L: Molecular characterization of dimeric alpha-amylase inhibitor genes in wheat and development of genome allele-specific primers for the genes located on chromosome 3BS and 3DS. J Cereal Sci 2006, 43:360-368.

40. Sander I, Rozynek P, Rihs HP, van Kampen V, Chew FT, Lee WS, KotschyLang N, Merget R, Bruning T, Raulf-Heimsoth M: Multiple wheat flour allergens and cross- reactive carbohydrate determinants bind lgE in baker's asthma. Allergy 2011, 66:1208-1215.

41. Strobl S, Maskos K, Wiegand G, Huber R, Gomis-Rüth FX, Glockshuber R: A novel strategy for inhibition of alpha-amylases: yellow meal worm alphaamylase in complex with the Ragi bifunctional inhibitor at 2.5 A resolution. Structure 1998, 15:911-921.

42. Clifton LA, Lad MD, Green RJ, Frazier RA: Single amino acid substitutions in puroindoline-b mutants influence lipid binding properties. Biochemistry 2007, 46:2360-2366.

43. Feiz L, Wanjugi HW, Melnyk CW, Altosaar I, Martin JM, Giroux MJ: Puroindolines co-localize to the starch granule surface and increase seed-bound polar lipid content. J Cereal Sci 2009, 50:91-98.

44. Kim KH, Feiz I, Martin JM, Giroux MJ: Puroindolines are associated with decreased polar lipid breakdown during wheat seed development. J Cereal Sci 2012, 52:142-146.

45. Pauly A, Pareyt B, Fierens E, Dalcour JA: Wheat (Triticum aestivum L. and T. turgidum L. ssp. durum) kernel hardness: I. Current view on the role of puroindolines and polar lipids. Compr Rev Food Sci F 2013, 12:413-426. 
46. Brodersen $\mathrm{P}$, Voinnet $\mathrm{O}$ : The diversity of RNA silencing pathways in plants. Trends Genet 2006, 22:268-280.

47. Ossowski S, Schwab R, Weigel D: Gene silencing in plants using artificial microRNAs and other small RNAs. Plant J 2008, 53:674-690.

48. Lesage VS, Bouchet B, Rhazi I, Elmorjani K, Branland G, Marion D: New insight into puroindoline function inferred from their subcellar localization in developing hard and soft near-isogenic endosperm and their relationship with polymer size of storage proteins. J Cereal Sci 2011, 53:231-238.

49. Shewry PR, Mitchell RAC, Tosi P, Wan Y, Underwood C, Lovegrove A Freeman J, Toole GA, Mills ENC, Ward Jl: An integrated study of grain development of wheat (cv. Hereward). J Cereal Sci 2012, 56:21-30.

50. Lawrence RJ, Pikaard CS: Transgene-induced RNA interference: a strategy for overcoming gene redundancy in polyploids to generate loss-offunction mutations. Plant J 2003, 36:114-121.

51. Wilkinson M, Wan $Y$, Tosi P, Leverington M, Snape J, Mitchell RAC, Shewry PR: Identification and genetic mapping of variant forms of puroindoline b expressed in developing wheat grain. J Cereal Sci 2008, 48:722-728.

52. Chen F, Beecher BS, Morris CF: Physical mapping and a new variant of Puroindoline b-2 genes in wheat. Theor Appl Genet 2010, 120:745-751.

53. Chen F, Xu H-X, Zhang F-Y, Xia X-C, He Z-H, Wang D-W, Dong Z-D, Zhan K$\mathrm{H}$, Cheng $X-Y$, Cui D-Q: Physical mapping of Puroindoline $b$-2 genes and molecular characterization of a novel variant in durum wheat (Triticum turgidum L.). Mol Breed 2011, 28:153-161.

54. Geng H, Beecher BS, Zhonghu H, Kiszonas AM, Morris CF: Prevalence of Puroindoline D1 and Puroindoline b-2 variants in U.S. Pacific Northwest wheat breeding germplasm pools, and their association with kernel texture. Theor Appl Genet 2012, 124:1259-1269.

55. Giroux MJ, Kim K-H, Hogg AC, Martin JM, Beecher B: The Puroindoline b-2 variants are expressed at low levels relative to the Puroindoline $D 1$ genes in wheat seeds. Crop Sci 2013, 53:833-841.

56. Pearson T, Wilson J, Gwirtz J, Maghirang E, Dowell F, McCluskey P, Bean S: Relationship between single wheat kernel particle-size distribution and Perten SKCS 4100 Hardness Index. Cereal Chem 2007, 84:567-575.

57. Fox GP, Osborne B, Bowman J, Kelly A, Cakir M, Poulsen D, Inkerman A, Henry R: Measurement of geneticand environmental variation in barley (Hordeum vulgare) grain hardness. J Cereal Sci 2007, 46:82-92.

58. Takahashi A, Ikeda TM, Takayama T, Yanagisawa T: A barley Hordoindoline mutation resulted in an increase in grain hardness. Theor Appl Genet 2010, 120:519-526.

59. Jing W, Demcoe AR, Vogel HJ: Conformation of a bacterial domain of puroindoline a: structure and mechanism of action of a 13-residue antimicrobial peptide. J Bacteriology 2003, 185:4938-4947.

60. Haney EF, Peterson AP, Lau CK, Jing W, Storey DG, Vogel HJ: Mechanism of action of puroindoline derived tryptophan-rich antimicrobial peptides. Bioch Biophys Acta 1828, 2013:1802-1813.

61. Lesage VS, Merlino M, Chambon C, Bouchet B, Marion D, Branlard G: Proteomes of hard and soft near-isogenic wheat lines reveal that kernel hardness is related to the amplification of a stress response during endosperm development. J Exp Bot 2012, 63:1001-1011.

62. Murray AA, Thompson WF: Rapid isolation of high molecular weight plant DNA. Nucleic Acids Res 1980, 8:4321-4325.

63. Lillemo M, Chen F, Xia X, William M, Pena RJ, Trethowan R, He Z Puroindoline grain hardness alleles in CIMMYT bread wheat germplasm. J Cereal Sci 2006, 44:86-92.

64. Prescott A, Martin C: A rapid method for the quantitative assessment of levels of specific mRNAs in plants. Plant Mol Biol Rep 1987, 4:219-224.

65. Scofield SR, Huang L, Brandt AS, Gill BS: Development of a virus-induced gene silencing system for hexaploid wheat and its use in functional analysis of the Lr21-mediated leaf rust resistance pathway. Plant Physiol 2005, 138:2165-2173.

66. Bettge $A D$, Morris $C F$, Greenblatt GA: Assessing genotypic softness in single wheat kernels using starch granule associated friabilin as a biochemical marker. Euphytica 1995, 86:65-72.
67. Chang C, Zhang H, Xu J, Li W, Liu G, You M, Li B: Identification of allelic variations of puroindoline genes controlling grain hardness in wheat using a modified denaturing PAGE. Euphytica 2006, 152:225-234.

68. Laemmli UK: Cleavage of structural proteins during the assembly of the head of bacteriophage T4. Nature 1970, 227:680-685.

69. Gromova I, Celis JE: Protein detection in gels by silver staining: a procedure compatible with mass spectrometry. In Cell biology: A Laboratory Handbook, Volume 4. Edited by Celis JE, Carter N, Hunter T, Shotton D, Simons K, Small JV. San Diego, CA: Elsevier; 2004:219-223.

doi:10.1186/1471-2229-13-190

Cite this article as: Gasparis et al.: Sina and Sinb genes in triticale do not determine grain hardness contrary to their orthologs Pina and Pinb in wheat. BMC Plant Biology 2013 13:190.

\section{Submit your next manuscript to BioMed Central and take full advantage of:}

- Convenient online submission

- Thorough peer review

- No space constraints or color figure charges

- Immediate publication on acceptance

- Inclusion in PubMed, CAS, Scopus and Google Scholar

- Research which is freely available for redistribution 